\title{
The trophic role and impact of plankton ciliates in the microbial web structure of a tropical polymictic lake dominated by filamentous cyanobacteria
}

\author{
Alfonso ESQUIVEL, ${ }^{1,2^{*}}$ Aude BARANI, ${ }^{3}$ Miroslav MACEK,${ }^{4}$ Ruth SOTO-CASTOR,,${ }^{1}$ Celia BULIT ${ }^{1}$ \\ ${ }^{1}$ Departamento el Hombre y su Ambiente, Universidad Autónoma Metropolitana, Xochimilco, México D.F.; ${ }^{2}$ Doctorado en Ciencias \\ Biológicas y de la Salud, Universidad Autónoma Metropolitana, Xochimilco, México D.F.; ${ }^{3}$ PRECYM - Regional Flow Cytometry \\ Platform for Microbiology. Mediterranean Institute of Oceanography (MIO UM 110) OCEANOMED, OSU, Pytheas, Case 901, Campus \\ Luminy, 13288 Marseille Cedex 9, France; ${ }^{4}$ FES Iztacala, Departamento de Investigación en Limnología Tropical, Universidad Nacional \\ Autónoma de México, Tlalnepantla, Edo. México, México \\ *Corresponding author: aesquiv@correo.xoc.uam.mx
}

\begin{abstract}
The recent interest in the plankton structures and dynamics in tropical and subtropical lakes has revealed important trends that set these lakes apart from temperate lakes, and one of the main differences is the enhanced importance of the microbial food web with respect to net plankton. Ciliates are a key component of subtropical and tropical microbial webs because of their role as dominant picoplankton grazers and their ability to channel picoplankton production to the uppermost trophic levels. Plankton ciliates have been found to play a crucial role in the survival of fish larvae in lakes that share several features with Lake Catemaco, a eutrophic tropical Mexican lake. Therefore, the plankton ciliate composition, abundance, and biomass of Lake Catemaco were studied to assess their role in the microbial food web. The data were obtained from surface and bottom water samples collected at eleven points during three surveys in 2011 and an additional survey in 2013, with the surveys covering the local climatic seasons. The most abundant components of the plankton ciliate assemblages were small prostomatids (Urotricha spp.), choreotrichs (Rimostrombidium spp.), cyclotrichs (Mesodinium and Askenasia), and scuticociliates (Cyclidium, Cinetochilum, Pleuronema, and Uronema). Other important ciliates in terms of abundance and/or biomass were haptorids (Actinobolina, Belonophrya, Monodinium, Paradileptus, and Laginophrya), Halteria, oligotrichs (Limnostrombidium and Pelagostrombidium), Linostomella, Bursaridium, Cyrtolophosis, and Litonotus. The ciliate abundance averaged 57 cells $m L^{-1}$ and ranged from 14 to 113 cells $m L^{-1}$. The mean ciliate biomass was $71 \mu g C L^{-1}$ and ranged from 10 to $202 \mu \mathrm{g} \mathrm{C} \mathrm{L} \mathrm{L}^{-1}$. Differences were not detected in ciliate abundance or biomass between the sampling points or sampling depths (surface to bottom); however, significant differences were observed between seasons for both variables. Nano-sized filamentous cyanobacteria were the most abundant component of the plankton, and their abundance was assessed through epifluorescence microscopy counts. The autotrophic and heterotrophic picoplankton abundance was measured through epifluorescence, and their abundance and biomass were higher at the study site relative to other shallow freshwater ecosystems. The total ciliate biomass distribution patterns were similar to those of filamentous cyanobacteria and autotrophic or heterotrophic picoplankton, although the nanociliate biomasses peaked when the picoplankton and filamentous cyanobacteria were least abundant. The consequences of this increased importance of ciliates on the structure of the plankton at Lake Catemaco will be discussed along with the probable causes.
\end{abstract}

Key words: Cylindrospermopsis; eutrophic; microbial food web; nanociliates; picoplankton.

Received: March 2015. Accepted: November 2015.

\section{INTRODUCTION}

Recently, microbial communities in shallow tropical lakes have received increasing attention (Sarmento, 2012), and their key importance to the structure and function of temperate lake ecosystems has been acknowledged. The microbe-related changes occurring in these lakes are relevant because of their impact on water quality and their likely increase through climate change in particular (Kosten et al., 2012). Ciliates have the potential to play a pivotal role in these processes because of their ability to control harmful algal blooms (Davis et al., 2012) and act as an interface between picoplankton and mesozooplankton (Sherr and Sherr, 2002).

Lake Catemaco is a eutrophic tropical lake that has suffered from the impacts of human activities, particularly over the last forty years. The limnological records on the conditions of the lake prior to 1980 are scarce as to determine whether the current plankton communities are the product of environmental degradation or normal ontogenetic stages. Catemaco is an important lake in the country based on its fisheries and biological productivity (TorresOrozco and Pérez-Rojas, 1995) as well as the presence of endemic fish species (Miller and Van Conner, 1997). The local social and economic welfare largely depend on the lake's health; thus, it is important to monitor its condition. The microbial food web components in this lake have not been previously investigated. The only well-described feature is the domination of the microbial web and the en- 
tire pelagic environment at Catemaco by filamentous cyanobacteria (Komárková and Tavera, 1996). The relative importance of ciliates appears to be higher in polymictic lakes where these cyanobacteria are abundant than in other temperate lakes (Zingel et al., 2007). Moreover, the ciliate importance to the food web increases with higher primary productivity (Sherr and Sherr, 2002), although it remains to be shown if this relationship holds true for tropical lakes, such as Catemaco.

The nature of lacustrine trophic microbial web components and their interactions have been studied for temperate lakes with different trophic statuses (Straškrabová et al., 1999; Pfister et al., 2002; Auer et al., 2004; Chróst et al., 2009; Agasild et al., 2013; Van Wichelen et al., 2013), including eutrophic temperate lakes affected by cyanobacterial blooms (Moustaka-Gouni et al., 2006; Zingel et al., 2007; Zingel and Nõges, 2010), shallow soda lakes of Africa (Burian et al., 2013), relatively shallow eutrophic lakes, deep oligotrophic tropical lakes of Eastern Africa (Yasindi and Taylor, 2003), deep athalassohaline lakes of North America (Macek et al., 2008; Peštová et al., 2008), and shallow subtropical lakes with differing trophic statuses (Beaver and Crisman, 1989; Beaver and Crisman, 1990; Gomes and Godinho, 2003; MachadoVelho et al., 2005; Havens et al., 2007; Bagatini et al., 2013; Machado-Velho et al., 2013). These studies have demonstrated that microbial food webs, particularly the composition, abundance, biomass and diversity of ciliates, present specific responses to the geographic, climatic and ecological features of different lakes and reservoirs. A meta-analysis has shown that the trends observed in temperate lakes cannot be extrapolated to tropical lakes. Small forms of plankton dominate tropical lake communities, and their presence corresponds to a diminished efficiency in biomass transfer to the uppermost trophic levels (Sarmento, 2012). Microbial webs are more important in tropical lakes and filamentous cyanobacteria-dominated lakes (Davis et al., 2012), a condition that has obvious impacts on fisheries. Torres-Orozco and Zanatta (1998) reported low densities of net zooplankton for Catemaco that are dominated by rotifers, including genera reported as potential competitors or predators of small ciliates (Sanders et al., 1994; Weisse and Frahm, 2002). Catemaco's depauperated net zooplankton and profuse filamentous cyanobacteria growth may affect the preypredator interactions among microbial web components. The prevailing conditions at Catemaco indicate the enhanced importance of microbial webs, particularly of the plankton ciliate assemblages. Plankton ciliates drive biomass from autotrophic and heterotrophic picoplankton to upper trophic levels; therefore, the abundance of autotrophic and heterotrophic picoplankton abundance was simultaneously recorded. Based on their size and other features, plankton ciliates are the most likely food source for first-feeding larvae of fish species that support local fisheries, and because this stage is considered critical in fish life cycles, the maintenance of fish stocks depends on ciliates (Zingel et al., 2012). The selective filter-feeding activity of these fish species is believed to be at least partially responsible for Catemaco's plankton composition (Kormákova and Tavera, 2003). Therefore, the composition, abundance, and biomass of plankton ciliates were studied to assess their trophic role in the microbial food web of Lake Catemaco and determine how the ciliate assemblages respond to tropical, eutrophic, and polymictic environments that are dominated by filamentous cyanobacteria and impacted by human activities.

\section{METHODS}

\section{Study site}

Lake Catemaco is delimited by the coordinates $18^{\circ} 17^{\prime}$ to $18^{\circ} 21^{\prime} \mathrm{N}$ and $95^{\circ} 01^{\prime}$ to $95^{\circ} 07^{\prime} \mathrm{W}$ (Fig. 1), and it is located next to Los Tuxtlas, the last stand of what was once an extensive tropical forest, which is $20 \mathrm{~km}$ from the Gulf of Mexico at an altitude of $332 \mathrm{~m}$ a.s.l. Catemaco is a eutrophic lake, volcanic in origin and has a main length of $12.32 \mathrm{~km}$ and a maximum width of $10.25 \mathrm{~km}$, with an area of $72.5 \mathrm{~km}^{2}$ (Pérez-Rojas and Torres-Orozco, 1992). The mean depth is $7.6 \mathrm{~m}$, and the volume is $5.23 \times 10^{8} \mathrm{~m}^{3}$. The profile of the lake resembles that of a pan with a relative depth of $\mathrm{z}_{\mathrm{r}}=0.23 \%$, which results in water column instability and frequent mixing by the winds blowing through this region. Brief stratification events generally occur in October (Torres-Orozco et al., 1996).

Three seasons occur in this region: a rainy season from July to October, a north winds season from November to March, and a dry season from April to June. The average rainfall is at least $2000 \mathrm{~mm}$ per year, and it primarily occurs from July to October, although the north winds are occasionally associated with rain. Catemaco's only drain is through the Rio Grande de San Andrés at its northwestern shore. Tavera (1996) estimated an average water retention time of 0.875 years for Lake Catemaco during the period from 1991-1994. The catchment basin surrounding this eutrophic lake was originally covered by tropical forest; however, with the exception of stands at its eastern shore, the area has been cleared for agricultural, livestock husbandry or urban purposes. Although raw sewage from the town of Catemaco is not discharged into the lake, heavy rainfall results in overflow from the sewer system into the lake (Esquivel et al., 2009).

\section{Sample collection}

For sample collection, ten points were set at the lake's periphery and a further point was located at the lake's center. Water samples were collected with a 2 litre van Dorn sampler in March (north winds season), May 
(dry season) and October (rainy season) 2011 and May 2013 (dry season) at $0.3 \mathrm{~m}$ from the surface and $0.3 \mathrm{~m}$ above the bottom. One hundred millilitre aliquots were drawn, with one aliquot fixed with $0.2-\mu \mathrm{m}$-filtered formalin to a final concentration of $2 \%$ for epifluorescence (Kepner and Pratt, 1993; Straškrabová et al., 1999) and another fixed with 2\% acid Lugol's iodine solution for plankton counting under an inverted microscope. The samples for the quantitative protargol stain (QPS) were fixed with Bouin's fixative at a final concentration of 7\% (Montagnes and Lynn, 1987).
Light measurements were not performed, but the Poole and Atkins equation (Idso and Gilbert, 1974) was employed to calculate the average extinction coefficient for water from the Secchi disk depth (Idso and Gilbert, 1974). This value was then used to determine the depth at which $1 \%$ of the incident light would occur.

The physical, chemical and biological variables were measured, including the temperature, conductivity, Secchi disk depth, $\mathrm{pH}$, dissolved oxygen (Winkler's method; APHA et al., 1992), nitrate-N, nitrite-N, ammonia-N, soluble reactive phosphorus (SRP) were spectrophotometri-

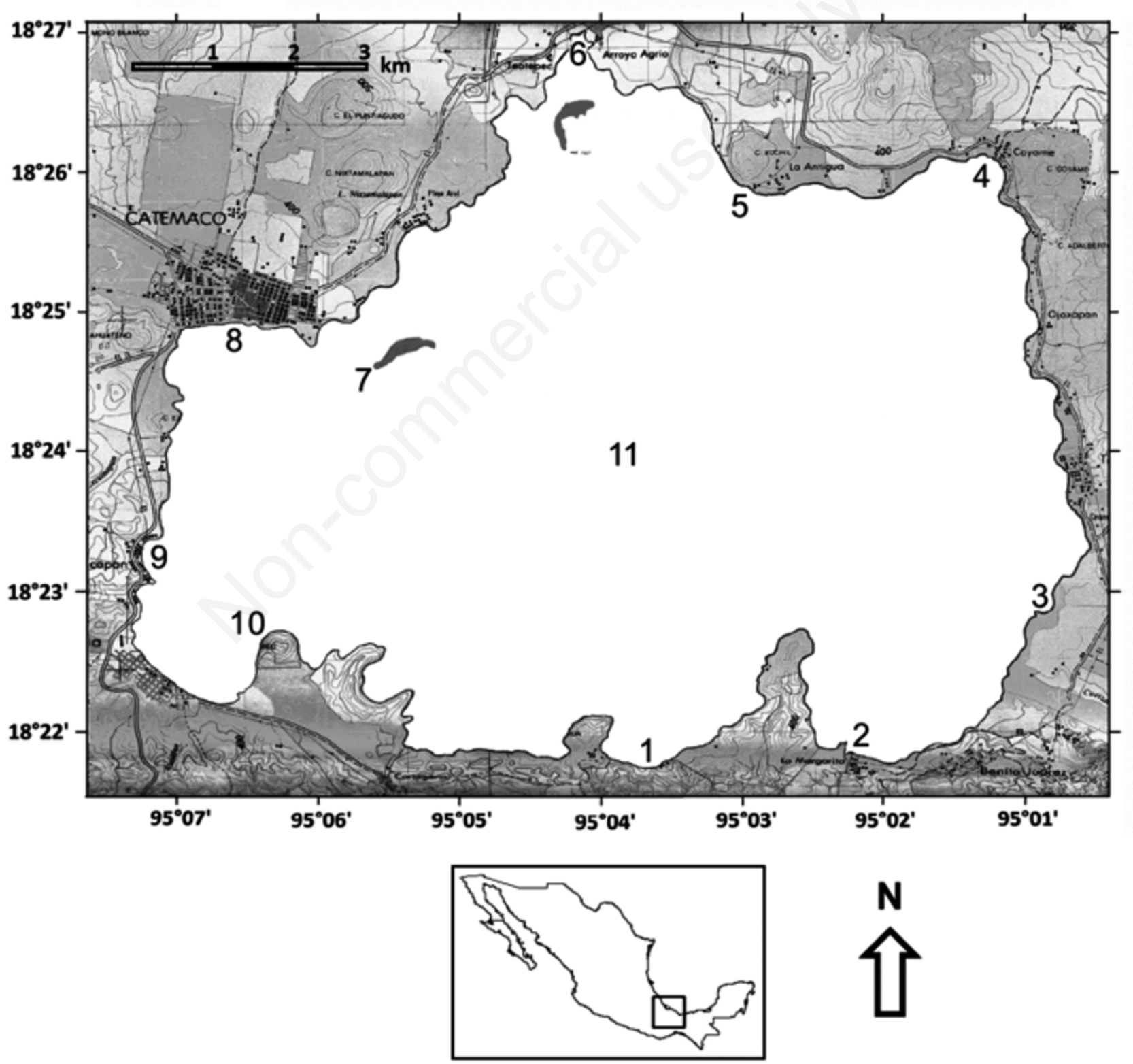

Fig. 1. Lake Catemaco. Location and sampling points. 
cally measured (APHA et al., 1992), and total P, which was measured after a sodium persulphate digestion. The soluble inorganic N:P ratios were calculated from these measurements, and chlorophyll $a$ was assessed spectrophotometrically using the trichromatic method described by Jeffrey and Humphrey (1975).

\section{Prokaryote enumeration}

Sample processing was performed according to the Kepner and Pratt (1993) method through filtering on $0.22 \mu \mathrm{m}$ black polycarbonate membranes and staining with DAPI (4',6-diamidino-2-phenylindole) (Porter and Feig, 1980). Prokaryotes, including filamentous cyanobacteria, were enumerated from counts of at least 400 cells from a minimum of 20 fields (Straškrabová et al., 1999) under an Olympus BX53 epifluorescence microscope using a DAPI filter set (emission $420 \mathrm{~nm}$, excitation 330-385 nm, and dichroic mirror $400 \mathrm{~nm}$ ) for heterotrophic picoplankters and a chlorophyll filter set (emission $510 \mathrm{~nm}$, excitation 460-495 nm, dichroic mirror $505 \mathrm{~nm}$ ).

\section{Ciliate identification, abundance and biovolume}

Ciliates were identified to the least possible taxonomic level from QPS slides based on the methodology of Dragesco et al. (1986), Foissner and Berger (1996), and Foissner et al. (1999) and arranged according to the system of Lynn (2008). Other relevant information, such as the feeding habits, food source preferences, habitat and distribution, was determined from these sources.

Samples fixed with Bouin's fixative were passed through 3- $\mu \mathrm{m}$ mixed cellulose-ester filters and then QPS stained (Montagnes and Lynn, 1993; Skibbe, 1994). These slides were completely scanned to identify, count and measure the ciliates; however, the ciliate counts and biovolumes are reported for the samples fixed in Lugol's iodine because the counts and morphotype number were smaller in the QPS-stained samples. The Lugol's iodinefixed samples were homogenized and placed into $10-\mathrm{mL}$ Utermöhl's sedimentation chambers and allowed to settle for $24 \mathrm{~h}$ (Hasle, 1978). They were then analyzed with a Zeiss Axiovert 25 CFL inverted microscope at $400 \times$ magnification. One-half of the chamber bottom was observed for ciliate enumeration. At least 30 organisms were measured for each morphotype to calculate their biovolumes by comparing their forms to those of standard geometrical bodies (Hillebrand et al., 1999). The factor $190 \mathrm{fg} \mathrm{C} \mu \mathrm{m}^{-3}$ for the Lugol's iodine-fixed samples (Putt and Stoecker, 1989) was employed to calculate the biomass from the biovolume because this factor considers the ciliate shrinkage of the fixed samples (Gifford and Caron, 2000). The ciliate biomasses were further divided into total ciliates and nanociliates.

\section{Statistical analysis}

A non-parametric Kruskal-Wallis analysis of variance (ANOVA) was employed to detect the significant differences in the abundance and biomass associated with factors such as the season, sampling points, and sampling depth because the conditions for a parametric ANOVA, including a normal data distribution and homoscedasticity (Sokal and Rohlf, 2012), were not met. A pairwise Tukey's HSD test was employed as a post-hoc test to determine the cases with significant differences. These tests were performed with the software Statistica 7 (StatSoft, Tulsa, OK, USA).

\section{RESULTS}

\section{Physico-chemical and ecological background}

Windy conditions occurred during the surveys except for those in the dry season of 2013. The water temperature was $\geq 22^{\circ} \mathrm{C}$ and $\leq 30^{\circ} \mathrm{C}$ for the survey period. The average Secchi disk depth was $0.77 \mathrm{~m}$; thus, the euphotic zone consisted of a depth to $z_{\mathrm{eu}}=2.2 \mathrm{~m}$. Therefore, because the lake's mean depth is $7.6 \mathrm{~m}$, a sizable fraction of the lake's water would receive less than $1 \%$ of the surface light.

The total ammonia content ranged from non-detectable values up to $5.21 \mu \mathrm{M}$, to $2.86 \mu \mathrm{M}$ for nitrite, and to $1.60 \mu \mathrm{M}$ for nitrate. The SRP concentrations varied from $0.26 \mu \mathrm{M}$ to $63.63 \mu \mathrm{M}$, significant differences in SRP, detected through Kruskal-Wallis ANOVA occurred among surveys $(\mathrm{H}=49.25, \mathrm{P}<0.0001)$ but not among sampling depths $(\mathrm{H}=0.87, \mathrm{P}=0.352)$. The $\mathrm{N}: \mathrm{P}$ ratios were $\leq 2.40$ for the three 2011 surveys and up to 8.53 were attained for the dry season of 2013, although the values for 2013 were also likely indicative of N limitations. Significant differences for N:P ratios between the surveys were detected through the Kruskal-Wallis ANOVA $(\mathrm{H}=54.48$, $\mathrm{P}<0.0001)$, whereas no differences were detected between sampling depths $(\mathrm{H}=0.87, \mathrm{P}=0.35)$. The increased $\mathrm{N}: \mathrm{P}$ ratio during the dry season of 2013 was caused by a decrease in the SRP rather than the higher concentrations of DIN species (Tab. 1).

The chlorophyll $a$ concentrations ranged from 2 to $154 \mu \mathrm{g} \mathrm{L}^{-1}$ (Tab. 1). The Kruskal-Wallis ANOVA detected significant differences among surveys $(\mathrm{H}=23.00$, $\mathrm{P}<0.0001$ ), but not significant among sampling depths $(\mathrm{H}=0.45, \mathrm{P}=0.504)$. The lowest values occurred during the rainy season of 2011, and the highest values of 154 $\mu \mathrm{g} \mathrm{L}^{-1}$ and $130 \mu \mathrm{g} \mathrm{L}^{-1}$ occurred at the bottom in the south region of the lake and at the surface center during the dry season of 2011, respectively. In addition to the everdominant Cylindrospermopsis (Seenayya and Subbaraju, 1972), the most abundant phytoplankton organisms were the chain-forming diatom Aulacoseira granulata (Ehrenberg) (Simonsen, 1979) and the filamentous cyanobacteria Planktolyngbya regularis (Kormákova and Tavera, 
1996). The small pennate diatoms Cymbella minuta (Hilse, 1862), Navicula exigua (Patrick, 1945) and Gomphonema spp. (Ehrenberg, 1832) were also abundant. The most abundant metazoan plankton included rotifers of the genera Brachionus (Pallas, 1776), Keratella (Bory De St. Vincent, 1822), Trichocerca (Lamarck, 1801), and Hexarthra (Schmarda, 1854).

\section{Prokaryote abundances}

The bacterial abundances were $2.37 \times 10^{5}$ cells $\mathrm{mL}^{-1}$ to $5.47 \times 10^{6}$ cells $\mathrm{mL}^{-1}$, and definite distribution patterns were not observed for the surveys (Kruskal-Wallis test $\mathrm{H}=3.44, \mathrm{P}=0.97$ for the sampling points). However, the abundance significantly differed between the survey seasons $(\mathrm{H}=62.61, \mathrm{P}<0.0001)$ and had higher values during the north wind season of 2011 and the dry season of 2013, a trend that was also observed for the picocyanobacteria and filamentous cyanobacteria. For both the surface and bottom samples, the lowest bacterial densities were found throughout the lake during the rainy season of 2011, whereas higher densities occurred during the north wind season of 2011 and the dry season of 2013; the same pattern occurred for picocyanobacteria and filamentous cyanobacteria (Fig. 2).

The bacterial densities did not differ between the sur- face and bottom samples $(\mathrm{H}=0.42, \mathrm{P}=0.51)$, and this was also observed for the remaining microbial web components. The picocyanobacteria abundance ranged from $1.27 \times 10^{4} \mathrm{~mL}^{-1}$ to $8.05 \times 10^{5} \mathrm{~mL}^{-1}$ and presented the same trend as that of the filamentous cyanobacteria (see below), which had abundances that were noticeably lower in the dry and rainy season (in particular) of 2011 compared with that of the north wind season of 2011 and the dry season of $2013(\mathrm{H}=66.04, \mathrm{P}<0.0001)$. Spatially, definite patterns were not observed except for the lower abundances at the northernmost sampling point (6) and occasionally at the lake center (11) $(\mathrm{H}=2.01, \mathrm{P}=0.996$ for sampling points; $\mathrm{H}=0.32, \mathrm{P}=0.57$ for sampling depths) (Fig. 2). The filamentous cyanobacteria abundance ranged from $3.64 \times 10^{3}$ to $7.08 \times 10^{5}$ trichomes $\mathrm{mL}^{-}$ ${ }^{1}$ and density varied by approximately 100 fold from the dry and rainy seasons of 2011 to the bloom conditions in the north wind season of 2011 and the dry season of $2013(\mathrm{H}=62.23, \quad \mathrm{P}<0.0001)$. These filamentous cyanobacteria are $\mathrm{N}$-fixing nanoplanktic filamentous cyanobacteria, mostly from the Cylindrospermopsis genus. The most abundant was Cylindrospermopsis catemaco, which presents 2 to 4 cells per trichome (Komárková and Tavera, 1996). Differences were not detected between sampling points $(\mathrm{H}=6.33, \mathrm{P}=0.79)$ or sampling depths $(\mathrm{H}=0.07, \mathrm{P}=0.80)$ (Fig. 2).

Tab. 1. Physical, chemical and biological data for each survey and sampling depth.

\begin{tabular}{|c|c|c|c|c|c|c|c|c|}
\hline & North winds & North winds & Dry 2011 & Dry 2011 & Rainy 2011 & Rainy 2011 & Dry 2013 & Dry 2013 \\
\hline & 2011 & 2011 & Surface & Bottom & Surface & Bottom & Surface & Bottom \\
\hline & Surface & Bottom & & & & & & \\
\hline Temperature $\left({ }^{\circ} \mathrm{C}\right)$ & 23.9 & 24.0 & 28.1 & 28.3 & 25.2 & 25.0 & 25.2 & 25.2 \\
\hline & $23.0-25.0$ & $22.0-29.0$ & $25.1-30.0$ & $25.8-29.7$ & $24.7-26.0$ & $24.5-25.5$ & $24.0-26.0$ & $24.0-27.0$ \\
\hline Secchi disk depth (m) & 0.82 & & 0.66 & & 0.82 & & 0.80 & \\
\hline & $0.67-1.20$ & & $0.55-0.73$ & & $0.50-1.34$ & & $0.53-1.13$ & \\
\hline $\mathrm{z}_{\mathrm{eu}}(\mathrm{m})$ & 2.3 & & 1.9 & & 2.3 & & 2.2 & \\
\hline & $1.9-3.3$ & & $1.6-2.0$ & & $1.4-3.6$ & & $1.5-3.1$ & \\
\hline $\mathrm{pH}$ & 8.15 & 7.75 & 7.59 & 7.45 & 6.83 & 6.90 & 7.36 & 7.42 \\
\hline & $7.2-9.0$ & $7.2-8.3$ & $6.6-8.3$ & $6.3-8.4$ & $6.6-7.2$ & $6.4-7.5$ & $6.9-8.0$ & $7.0-7.9$ \\
\hline Dissolved oxygen $\left(\mathrm{mg} \mathrm{L}^{-1}\right)$ & 5.9 & 5.4 & 4.1 & 3.7 & 7.2 & 6.8 & 4.5 & 3.6 \\
\hline & $2.2-8.0$ & $3.9-9.3$ & $3.0-6.7$ & $2.6-4.8$ & $5.1-8.6$ & $3.3-8.2$ & $2.4-7.1$ & $0.0-6.4$ \\
\hline $\mathrm{NH}_{3}-\mathrm{N}(\mu \mathrm{M})$ & 1.40 & 1.39 & 1.61 & 2.21 & 0.35 & 0.52 & 0.69 & 0.60 \\
\hline & $0.00-2.16$ & $0.21-2.86$ & $0.04-5.21$ & $0.47-3.74$ & $0.16-0.57$ & $0.19-0.96$ & $0.09-1.57$ & $0.00-1.65$ \\
\hline$-\mathrm{NO}_{2}-\mathrm{N}(\mu \mathrm{M})$ & 0.23 & 0.21 & 0.38 & 0.37 & 0.28 & 0.30 & 1.09 & 0.41 \\
\hline & $0.00-0.85$ & $0.00-0.84$ & $0.02-1.03$ & $0.00-1.02$ & $0.03-0.82$ & $0.01-0.80$ & $0.00-2.38$ & $0.11-1.02$ \\
\hline$-\mathrm{NO}_{3}-\mathrm{N}(\mu \mathrm{M})$ & 0.06 & 0.06 & 0.03 & 0.06 & 0.54 & 0.52 & 0.01 & 0.01 \\
\hline & $0.00-0.17$ & $0.00-0.15$ & $0.00-0.09$ & $0.00-0.18$ & $0.16-1.07$ & $0.17-1.60$ & $0.00-0.03$ & $0.00-0.05$ \\
\hline $\operatorname{SRP}(\mu \mathrm{M})$ & 3.19 & 9.00 & 3.62 & 2.28 & 27.29 & 14.02 & 0.32 & 0.32 \\
\hline & $1.28-10.26$ & $1.33-44.18$ & $1.38-11.68$ & $0.63-4.16$ & $0.97-63.63$ & $1.10-61.63$ & $0.27-0.38$ & $0.26-0.40$ \\
\hline $\mathrm{N}: \mathrm{P}$ & 0.75 & 0.52 & 0.68 & 1.23 & 0.40 & 0.66 & 5.46 & 5.67 \\
\hline & $0.04-2.00$ & $0.10-1.34$ & $0.09-1.10$ & $0.73-1.71$ & $0.01-1.31$ & $0.02-2.40$ & $3.32-7.36$ & $2.62-8.58$ \\
\hline Chlorophyll $a\left(\mu \mathrm{g} \mathrm{L}^{-1}\right)$ & 62 & 62 & 97 & 99 & 60 & 60 & 70 & 82 \\
\hline & $20-100$ & $17-101$ & $25-130$ & $13-154$ & $22-97$ & $2-101$ & $10-97$ & $45-109$ \\
\hline
\end{tabular}

The data include the mean, minimum and maximum for each variable. 


\section{Ciliate identification}

Twenty-eight morphotypes were identified to the genus level, and they belonged to 18 orders (Tab. 2). Small choreotrichs, cyclotrichs, prostomatids, and scuticociliates were the most abundant forms in the assemblage containing algivorous heterotrichs, such as Linostomella, predaceous forms, such as Paradileptus and Litonotus, and organisms with other feeding strategies. The individual sizes ranged from $13 \mu \mathrm{m}$ to over $150 \mu \mathrm{m}$ in length.

\section{Ciliate abundance}

The ciliate abundance ranged from 14 cells $\mathrm{mL}^{-1}$ to 113 cells $\mathrm{mL}^{-1}$, and the average for the entire survey period was 57 cells $\mathrm{mL}^{-1}$. Differences were not detected between sampling points $(\mathrm{H}=10.70, \mathrm{P}=0.38)$ or sampling depths $(\mathrm{H}=0.10, \mathrm{P}=0.75)$, although highly significant differences were observed between survey seasons $(\mathrm{H}=46.92$, $\mathrm{P}<0.0001$ ). The ciliate abundances were higher during the rainy season of 2011 and particularly high during the dry season of 2013. The average abundance for the first two surveys was 40 cells $\mathrm{mL}^{-1}$, whereas the abundance for the last two surveys was 74 cells $\mathrm{mL}^{-1}$. This pattern is inconsistent with what was found for prokaryotes because the rainy season survey of 2011 presented low abundances and the north wind season survey of 2011 presented high abundances.

\section{Ciliate biomass}

The total ciliate biomass varied from $10 \mu \mathrm{g} \mathrm{C} \mathrm{L}^{-1}$ to $202 \mu \mathrm{g} \mathrm{C} \mathrm{L}^{-1}$. The Kruskal-Wallis ANOVA indicated significant differences between sampling points $(\mathrm{H}=19.00$, $\mathrm{P}=0.04)$, whereas Tukey's pairwise HSD test resulted in marginal differences $(\mathrm{P}=0.07$ and $\mathrm{Pp}=0.06$ for sampling points 1 and 2 and to point 10, respectively). The biomasses increased in October 2011 and especially in May 2013 ( $\mathrm{H}=20.27, \mathrm{P}<0.0001)$; however, significant differences were not observed for the sampling depth $(\mathrm{H}=1.25$, $\mathrm{P}=0.26$ ) (Fig. 3).
Tab. 2. Ciliate genera, arranged according to Lynn (2008).

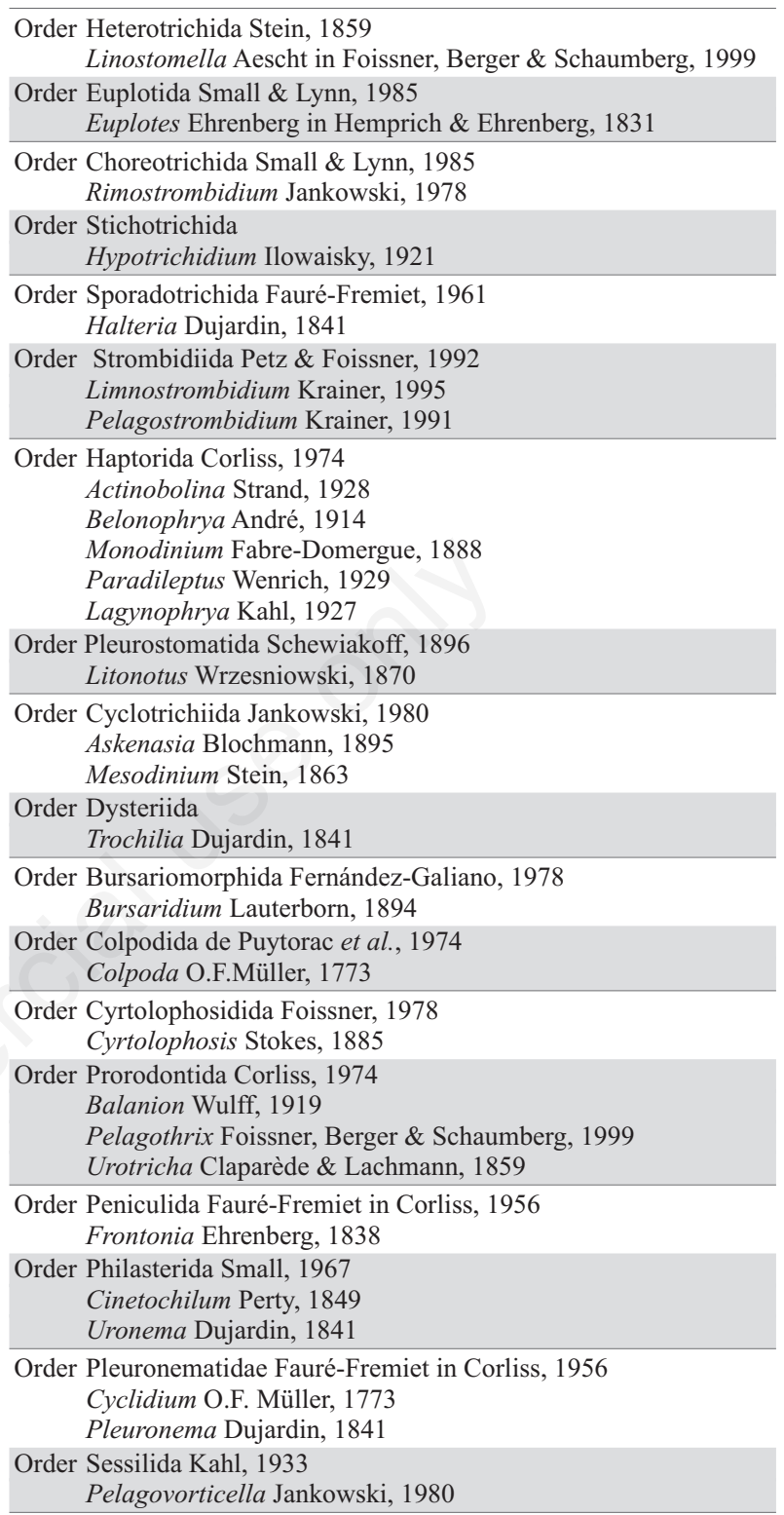
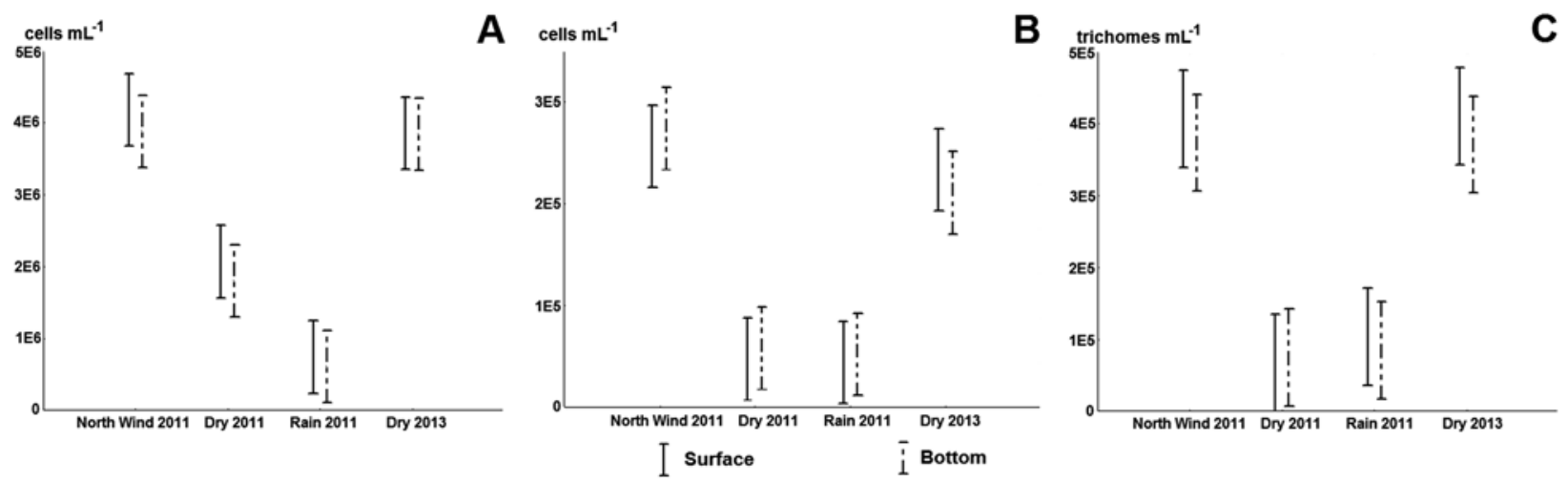

Fig. 2. Confidence intervals (0.95) of the mean for heterotrophic and autotrophic picoplankton (cells $\mathrm{mL}^{-1}$ ) and filamentous cyanobacteria (trichomes $\mathrm{mL}^{-1}$ ) per survey and sampling depth. A) Bacteria. B) Picocyanobacteria. C) Filamentous cyanobacteria. 
Nanociliates were defined as those with a maximum length $\leq 20 \mu \mathrm{m}$. The nanociliate biomass ranged from 1.9 $\mu \mathrm{g} \mathrm{C} \mathrm{L} \mathrm{C}^{-1}$ to $28.2 \mu \mathrm{g} \mathrm{C} \mathrm{L}^{-1}$, which was approximately $10 \%$ of the total ciliate biomass. Differences were not observed between sampling points $(\mathrm{H}=9.40, \mathrm{P}=0.49)$ nor sampling depths $(\mathrm{H}=2.54, \mathrm{P}=0.11)$; however, the differences between surveys were highly significant $(\mathrm{F}=18.94, \mathrm{P}<0.0001)$. Based on Tukey's HSD, significant pairwise differences were found between the bottom samples from the dry season of 2013 and the surface and bottom samples from the north wind season of 2011 ( $\mathrm{P}=0.013$ and $\mathrm{P}<0.0001$, respectively) as well for the bottom samples from the rainy season of 2011 ( $\mathrm{P}=0.001$ ) (Fig. 3). In addition to the general trends, ciliate biomass can also be described in more specific terms. The ciliate size was more important than the abundance for determining the total biomass per sample, which was demonstrated by the proportion of nanociliate biomass to the total ciliate biomass.

The morphotype biomass was pooled by group to provide a synoptic representation of the biomass (Fig. 4). Regardless of whether differences occurred between sampling points or sampling depths for the total and nanociliate biomass, the more detailed representation showed the differences between all of these factors. Despite their abundance, scuticociliates and small prostomatids provided a low contribution to the total ciliate biomass because of their small size. Scuticociliates were less abundant in the surface and bottom samples from the north wind season and reached their peak values of approximately $10 \mu \mathrm{g} \mathrm{C} \mathrm{L}^{-1}$ at a point northeast of the lake during the rainy season (Fig. 4). The prostomatids were least abundant at the surface and bottom during the dry season of 2011 and reached their peak values of approximately $20 \mu \mathrm{g} \mathrm{C} \mathrm{L}^{-1}$ in a bottom sample from the north wind season in a southwest region of the lake (Fig. 4).Choreotrichs were more abundant when picoplankton densities were high, i.e. the north wind season 2011 and the dry season 2013, and were particularly rare in the dry season 2011 (Fig. 4). In the north wind season, choreotrichs and oligotrichs presented higher biomass (close to $10 \mu \mathrm{g} \mathrm{C} \mathrm{L}^{-1}$ ) in the surface samples, whereas in the dry season of 2013, the highest values occurred in the bottom samples, particularly at a point west of the lake for oligotrichs, which reached $15 \mu \mathrm{g} \mathrm{C} \mathrm{L}^{-1}$ (Fig. 4). Low cyclotrich biomass was observed in the surface samples from the north wind season, and the peak biomass of 40

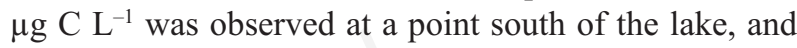
the lowest biomass in the bottom samples occurred during the dry and rainy seasons of 2011, whereas the maximum biomass of $30 \mu \mathrm{g} \mathrm{C} \mathrm{L}^{-1}$ occurred at a point in the northeast region of the lake (Fig. 4 ).

Haptorids were present at all of the sampling points and primarily represented by the small and ubiquitous Actinobolina and Belonophrya and the larger and frequent Lagynophrya; however, the peak values of $>50 \mu \mathrm{g} \mathrm{C} \mathrm{L}^{-1}$ were observed in a surface sample southeast of the town of Catemaco during the north wind season, and other high biomass values were observed in the surface and bottom samples of the dry season of 2011, which was caused by the presence of the more sparsely distributed Monodinium and the large Paradileptus, in particular (Fig. 4).

Linostomella was scarce in the surface and bottom samples from the rainy season and abundant in the surface and bottom samples from the dry season of 2011; how-

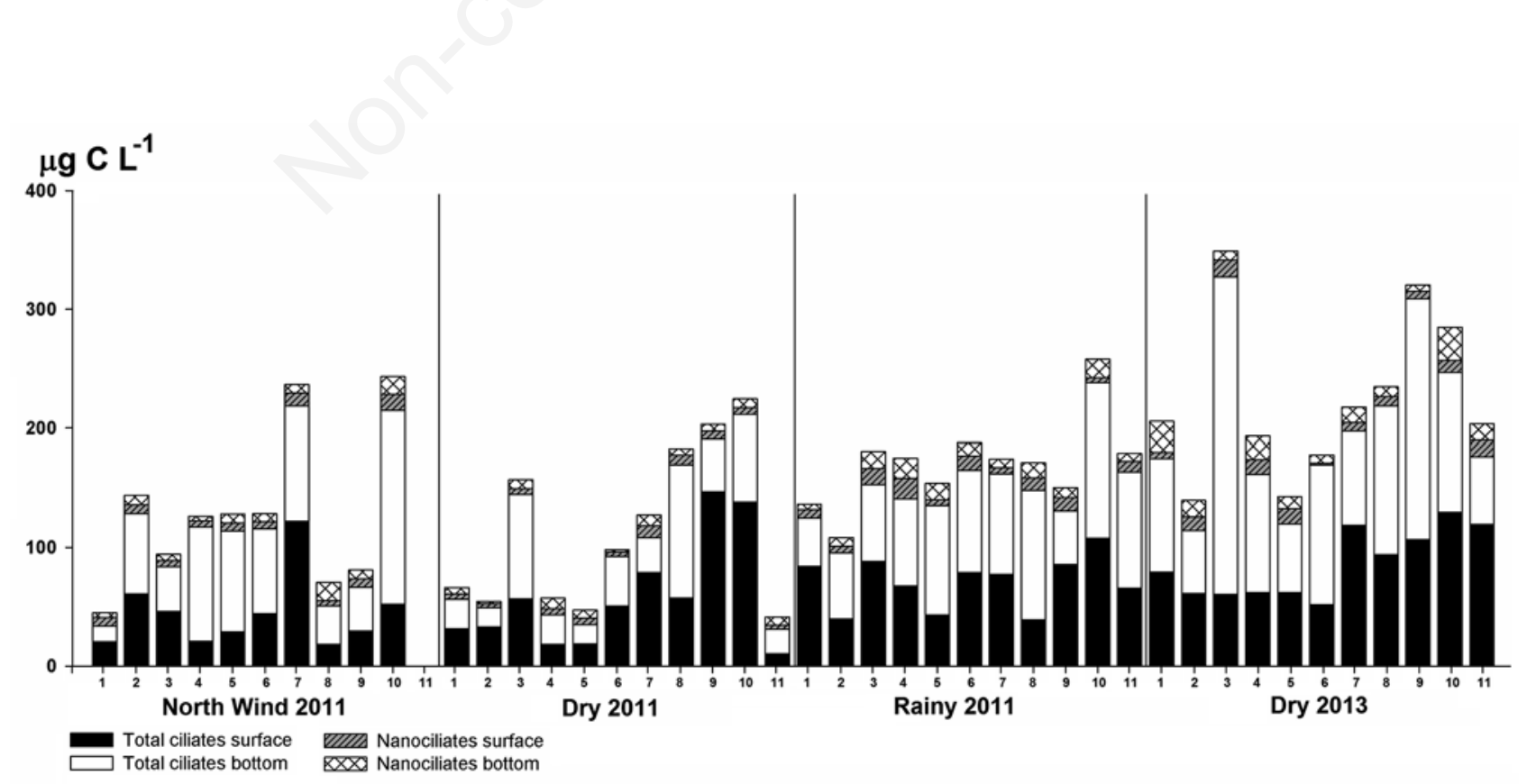

Fig. 3. Total ciliate and nanociliate biomass per sample $\left(\mu \mathrm{g} \mathrm{C} \mathrm{L}^{-1}\right)$ for surface and bottom samples. 
ever, these organisms were particularly abundant in the bottom samples from the north wind season and presented values of $50 \mu \mathrm{g} \mathrm{C} \mathrm{L}^{-1}$ in a region north of the lake. Litonotus was not observed in the dry season of 2011 and presented relatively low biomass except for a peak value close to $30 \mu \mathrm{g} \mathrm{C} \mathrm{L}^{-1}$ at a point southwest of the lake during the north wind season.

\section{DISCUSSION}

\section{Environmental background for ciliates}

Lake Catemaco is a eutrophic lake characterized by the profuse growth of $\mathrm{N}$-fixing filamentous cyanobacteria, and it is thoroughly mixed by wind. The data also indicate that this lake is light- and N-limited (Tab. 1), conditions that favour N-fixing cyanobacteria over other algal groups (Reynolds et al., 2002), and imply that $\mathrm{N}$ is trapped in the organic matter of these cyanobacteria and only available to other organisms through grazing or when a bloom decays and bacterial growth occurs (Engström-Öst et al., 2013). Therefore, bacterial growth can be limited when $\mathrm{N}$ limitation occurs, even if organic $\mathrm{C}$ is available (Mills et $a l ., 2008)$. This point is emphasized because sizable ciliate grazing activity on filamentous cyanobacteria was not observed; thus, the alternative prey species, especially for nanociliates, would have been bacteria and picocyanobac-
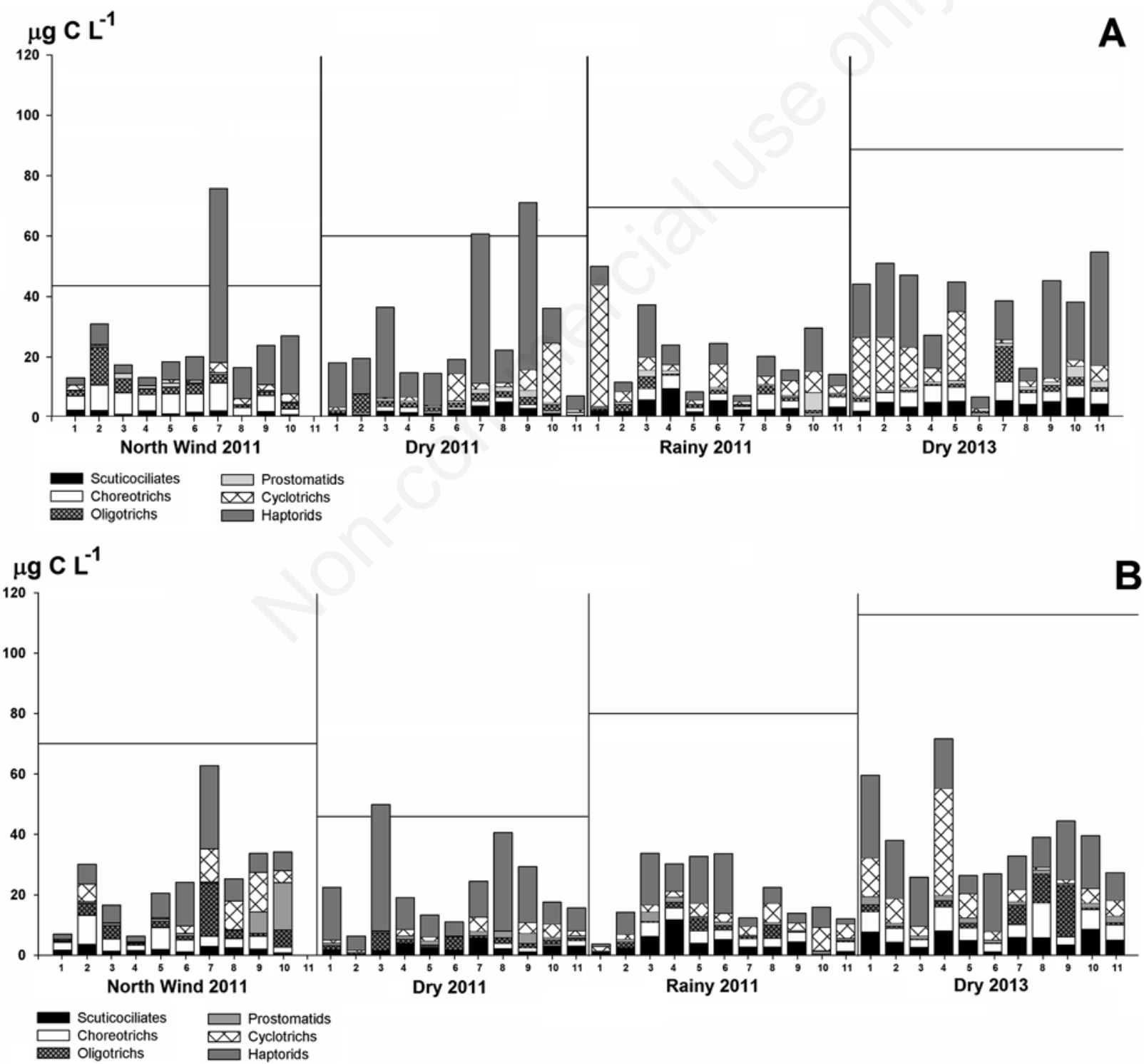

Fig. 4. Biomass per sample ( $\left.\mu \mathrm{g} \mathrm{C} \mathrm{L}^{-1}\right)$ for certain ciliate orders. Full lines are the average biomasses per survey and depth. A) Surface. B) Bottom water. 
teria (Sherr and Sherr, 2002). The highest bacterial density was $5 \times 10^{6}$ cells $\mathrm{mL}^{-1}$ during the period reported here, and this value is within the range for temperate mesotrophiceutrophic lakes (Wetzel, 2001). The bacterial cell morphologies were diverse at certain sampling points, and they were commonly dominated by micrococci along with filiform bacilli and certain bacterial aggregates, all of which are considered morphological responses to prevent their predation (Jürgens et al., 1997; Jürgens and Jeppesen, 2000; Pernthaler, 2005; Salcher, 2014). These changes are indicative of the pressure exerted by bacterivores.

The picocyanobacterial density was as high as $5 \times 10^{5}$ cells $\mathrm{mL}^{-1}$ for the epifluorescence microscopy counts, which is considered a high value (Sarmento et al., 2008), although their biomass was low with respect to the filamentous cyanobacteria, a common trend for systems with increasing trophic status (Callieri and Stockner, 2002). Nevertheless, because evidence of ciliate grazing on filamentous cyanobacteria was not observed, picoplankters appeared to represent the preferred food source, which would indicate that the abundances observed here are capable of sustaining sizable phagotrophic nanoprotist populations when associated with rapid turnover rates. An important fraction of $1 \mu \mathrm{m}$ to $2 \mu \mathrm{m}$ cells were observed under the microscope, and this size allows the organisms to be grazed by phagotrophic nanoplankters (Jürgens et al., 1999a).

The most noticeable feature of the plankton in Catemaco was the dominance by $\mathrm{N}_{2}$-fixing filamentous cyanobacteria, which occurred to such an extent that Komárková and Tavera (2003) described Cylindrospermopsis as forming a background for the rest of the plankton because of its overwhelming abundance. This condition appeared to be promoted by low N:P ratios that favour the growth of these organisms. $\mathrm{N}$ limitation has been described for systems where $\mathrm{P}$ inputs surpass $\mathrm{N}$ inputs, a condition that cannot always be overcome by biological $\mathrm{N}$ fixation (Mischler et al., 2014). Reynolds et al. (2002) related this state to a more complex interplay of conditions, including wind-induced mixing, relatively prolonged residence times for water (Tavera, 1996), and diminished light penetration of water, although Havens et al. (2003) found that low N:P ratios and diminished light penetration favoured non- $\mathrm{N}_{2}-$ fixing filamentous cyanobacteria at a tropical lake. All of these conditions occur at Catemaco.

Regarding other plankton components, chain-forming and small pennate diatoms and chlorophytes were abundant, even if they occurred in lower numbers compared with the filamentous cyanobacteria. Moreover, evidence of chain-forming and small pennate diatom consumption by the ciliate Linostomella was recorded. However, a number of rotifers, including Brachionus and Keratella species, have been found to compete with or even prey on small ciliates in laboratory experiments and in field conditions (Ventela et al., 2002; Weisse and Frahm, 2002), although they can also be preyed upon by large raptorial ciliates, such as Paradileptus (Foissner et al., 1999). Other predators of plankton ciliates are fish larvae, and a population of threadfin shad Dorosoma petenense at Catemaco supports a fishery. Because this shad is a clupeiform fish, its firstfeeding larvae are dependent on 35-45 $\mu \mathrm{m}$ prey, such as dinoflagellates or ciliates (Hunter, 1981). Ciliate are adequate as food sources for first-feeding fish larvae because feeding success is related to non-armoured prey, whereas feeding failure occurs with armoured dinoflagellates because these organisms may pass unaltered through the larval gut (Scura and Jerde, 1977; Lasker, 1981). Ciliates have been found to sustain the survival and growth of first-feeding larvae at other eutrophic shallow lakes (Zingel, 2012), and at Catemaco, they similarly sustain the threadfin shad fishery.

\section{Ciliate assemblage composition}

The ciliate composition to the genus level at Catemaco resembles the composition found at other shallow tropical freshwater ecosystems, such as those reported by Bagatini et al. (2013) for 13 Brazilian lakes or Beaver and Crisman $(1982,1989,1990)$ for eutrophic lakes in Florida. These findings may generalize to an almost cosmopolitan distribution throughout these aquatic systems (Pfister et al., 2002). Several of the observed morphotypes, such Uronema, Cyclidium, Rimostrombidium (Šimek et al., 1995; Zingel et al., 2007), Mesodinium, Colpoda (Foissner et al., 1999; Zingel and Nõges, 2010), and Halteria (Šimek et al., 1995), graze on picoplankton, these may include nanociliates which play an important role in energy and matter transfer through the microbial web because of the high metabolic rates associated with their small size.

For subtropical eutrophic lakes, Beaver and Crisman (1982) reported that small-bodied forms $(20-30 \mu \mathrm{m})$ replace larger ciliates as the trophic level increases. Because these authors considered that the smaller forms were essentially bacterivorous, they related this trend to a higher bacterial availability in eutrophic systems. Thus, the ciliate assemblage of the eutrophic Lake Catemaco is consistent with the size distribution proposed by Beaver and Crisman (1982) for subtropical lakes.

The ciliate assemblages also contained Actinobolina, Belonophrya, Mesodinium, Monodinium, and Lagynophrya, which prey on smaller protists, including ciliates (Foissner et al., 1999; Jürgens et al., 1999b; Zingel and Nõges, 2010). Several of the genera mentioned thus far have also been reported to graze on microalgae, such as Halteria, Mesodinium, Rimostrombidium, Limnostrombidium and Pelagostrombidium (Foissner et al., 1999; Zingel and Nõges, 2010), as well as certain larger ciliates, such as Bursaridium, and Linostomella, the latter of which is a particularly voracious grazer upon the chain-forming A. granulata and small pennate diatoms. Predatory forms, such as Paradileptus and Litonotus, were also found. 


\section{Ciliate abundance and biomass}

The microbial web components, including ciliates, have been found to increase in abundance and biomass along with the trophic level of freshwater ecosystems (Auer et al., 2004). As a eutrophic lake, Catemaco is consistent this trend because the ciliate abundance and biomass were both high compared with that of other temperate subtropical and tropical freshwater lakes of differing trophic statuses (Tab. 3).

The total ciliate and nanociliate biomass were lower during the north winds and dry seasons of 2011 and increased during the rainy season of 2011 and dry season of 2013 (Fig. 3). Therefore, the nanociliate abundance increased during the rainy season (third survey) when the bacteria, picocyanobacteria and filamentous cyanobacteria were least abundant. This apparent lack of correlation is inconsistent with what occurs in bottom-up-regulated ecosystems (by resources) (Auer et al., 2004; Zingel and Nõges, 2010), where significant correlations are found among ciliates and chlorophyll $a$ or picoplankton densi- ties. However, a careful follow-up of the nanociliate and picoplankton densities for several days would be necessary to determine if top-down control actually prevails or if the observed pattern observed was a result of picoplankton depletion by nanociliates. The ciliate biomass did not appear to be affected by the filamentous cyanobacteria density, which is inconsistent with what was found for a lake with toxic cyanobacterial blooms, where Cylindrospermopsis raciborskii (but not Microcystis aeruginosa) blooms depressed both the nanoflagellate and nanociliate assemblages (Moustaka-Gouni et al., 2006). The biomass distribution by morphotype differed between the surface and bottom samples despite the mixed character of the water column, and this result may be indicative of a patchy distribution (Fig. 4).

\section{Predation, filamentous cyanobacteria, and ciliate assemblage regulation}

Jürgens et al. (1999b) found abundant small ciliates at a temperate hypertrophic lake and determined that their

Tab. 3. Ciliate abundance and biomass at different freshwater lakes.

\begin{tabular}{|c|c|c|c|c|}
\hline Water body & Trophic status & $\begin{array}{l}\text { Ciliate abundance } \\
\text { cells }\left(\mathrm{mL}^{-1}\right)\end{array}$ & $\begin{array}{l}\text { Ciliate biomass } \\
\qquad\left(\mu g \mathrm{C} \mathrm{L}^{-1}\right)\end{array}$ & Reference \\
\hline Lake Oglethorpe, USA & Eutrophic & $110(\max )$ & & (Pace and Orcutt, 1981) \\
\hline Lake Lanao, Philippines & $\begin{array}{c}\text { Deep } \\
\text { Subtropical, eutrophic }\end{array}$ & 28 (avg) & & (Lewis, 1985) \\
\hline Lake Valencia, Venezuela & Eutrophic & 218 (avg) & & (Lewis, 1985) \\
\hline Rio Grande Reservoir, Brazil & Eutrophic & 17 & (Maluf- & f-Barbieri and Godinho-Orlandi, 1989) \\
\hline Lake Kingsley, USA & Oligotrophic & $45(\max )$ & & (Beaver and Crisman, 1990) \\
\hline East Lake, USA & Mesotrophic & $86(\max )$ & & (Beaver and Crisman, 1990) \\
\hline Lake Scott, USA & Eutrophic & 356 (avg) & & (Beaver and Crisman, 1990) \\
\hline Lake Houhu, China & Mesotrophic & 35.5 (avg) & & (Song, 2000) \\
\hline Lake Nani Tal, India & Eutrophic & $55-116(\min -\max )$ & & (Shukla and Gupta, 2001) \\
\hline $\begin{array}{l}\text { Lake Victoria, Tanzania } \\
\text { Lake Malawi, Tanzania }\end{array}$ & $\begin{array}{l}\text { Relatively shallow, } \\
\text { eutrophic deep, oligotrophic }\end{array}$ & $\begin{array}{c}20.1(\mathrm{avg}) \\
1.5(\mathrm{avg})\end{array}$ & $\begin{array}{l}36(24.2-61.8) \\
1.8(0.03-7.82)\end{array}$ & (Yasindi and Taylor, 2003) \\
\hline Lake Monte Alegre, Brazil & Eutrophic & $\begin{array}{l}389 \text { (surf.) } \\
97 \text { (bot.) }\end{array}$ & & (Gomes and Godinho, 2003) \\
\hline 55 lakes in North Germany & Different trophic statuses & & $\begin{array}{c}19(13-28) \text { mesotrophic } \\
30(22-40) \text { slightly eutrophic } \\
99(70-140) \text { very eutrophic } \\
132(88-198) \text { hypertrophic }\end{array}$ & (Auer et al., 2004) \\
\hline Irai Reservoir, Brazil & Eutrophic & $7.2-47.1(\min -\max )$ & & (Machado-Velho et al., 2005) \\
\hline $\begin{array}{l}\text { Six lakes in the Masurian } \\
\text { Lake District Poland }\end{array}$ & $\begin{array}{l}\text { Mesotrophic, eutrophic, } \\
\text { polyhumic }\end{array}$ & $\begin{array}{l}5.2-27.8 \text { (min-max } \\
\text { avg values) }\end{array}$ & $\begin{array}{c}14.9-90.0 \\
\text { mesotrophic-polyhumic }\end{array}$ & (Chróst et al., 2009) \\
\hline Lake Araras, Brazil & & $51.91(\max )$ & & (Bagatini et al., 2013) \\
\hline 13 water bodies in Brazil & & $14.89(2.03-61.10)$ & & (Bagatini et al., 2013) \\
\hline Lake Võrtsjärv & Shallow eutrophic & $\begin{array}{l}68 \text { (basal condition) } \\
35 \text { (excluding } \\
\text { mesozooplankton) }\end{array}$ & $\begin{array}{l}88 \text { (basal condition) } \\
94 \text { (excluding } \\
\text { mesozooplankton) }\end{array}$ & (Agasild et al., 2013) \\
\hline Urban lake, Brazil & Shallow eutrophic subtropical & $\begin{array}{l}3.50 \text { (surf.) } \\
17.99 \text { (bot.) }\end{array}$ & $\begin{array}{l}2.02 \text { (surf.) } \\
18.27 \text { (bot.) }\end{array}$ & (Machado-Velho et al., 2013) \\
\hline Monjolinho Reservoir, Brazil & Shallow eutrophic subtropical & $3.7-16.0$ & & (Hisatugo et al., 2014) \\
\hline Lake Catemaco & Shallow mesotrophic-eutrophic & $57(14-113)$ & $71.1(10.4-202.2)$ & This work \\
\hline
\end{tabular}


populations were regulated by predators (top-down) instead of by food availability (bottom-up). This result may indicate a trend whereby top-down control becomes more important for higher trophic states of subtropical lakes (Havens et al., 2007), and the authors stated that fish predation must exert a stronger top-down control on the pelagic food web in subtropical lakes than in temperate lakes of similar trophic status. Catemaco's plankton assemblage is the result of selective predation pressure by planktivorous fish, which prey on the larger zooplankton, including the large non-selective daphnids that graze on cyanobacterial trichomes and consume the more edible phytoplankton species, thus leaving behind trichome-enriched water (Komárková and Tavera, 2003). Physical interference by trichomes has been proposed as a mechanism that reduces ciliate predation, and it is an important process because top-down control by predatory fish likely has a strong effect on the microbial web of tropical lakes (Havens et al., 2007). Zingel et al. (2007) determined that ciliates are the dominant microbial grazers at a temperate lake that is also dominated by filamentous cyanobacteria because top-down control by fish predators did not occur under these conditions.

The dominant cyanobacteria at Catemaco produce toxins (Berry and Lind, 2010) that have unknown effects on other components of the microbial web, and the effect of these toxins on the ciliate assemblages is also unknown. The ingestion of Cylindrospermopsis by ciliates cannot be excluded because there is experimental evidence that toxin-producing filamentous cyanobacteria can sustain ciliate growth and survival (Fabbro et al., 2001; Combes et al., 2013). Fabbro et al. (2001) indicated that toxin-rich Cylindrospermopsis present straight trichomes, whereas the less toxic forms present coiled trichomes, and this prevents their attack by ciliates that ingest them end first. The dominant morphology at Catemaco during the surveys was coiled, such as a key ring. Large daphnids are regarded as natural control agents against filamentous cyanobacteria proliferation; however, at least one report has indicated that their filtering efficiency is negatively correlated with trichome density (Davis et al., 2012). Therefore, whether large cladocera would be able to control the Cylindrospermopsis densities found in Catemaco remains unclear. Further experimental evidence is required to determine whether large cladocera have been excluded for this reason or if their absence is because of the selective activity of planktophagus fish, including the native threadfin shad Dorosoma petenense (Günther, 1867), the endemic Bramocharax caballeroi (ContrerasBalderas and Rivera-Tiellery, 1985), or the exotic and more efficient tilapia Oreochromis niloticus (Linnaeus, 1758; Miller and Van Conner, 1997). The absence of these cladocera, which are non-selective filter-feeders that also prey on micro- and nanociliates, as well as on competing or predating rotifers, may cause cascading trophic effects (Sommer et al., 2003). Fish predation on zooplankton is believed to prevent microcrustaceans from preying on ciliates, and this results in a lower HNF biomass because of higher predation by ciliates (Ozen et al., 2014), which would also explain the low HNF abundances (results not shown) at Catemaco.

\section{CONCLUSIONS}

Plankton ciliate assemblages, particularly nanociliates, play an enhanced role in the microbial food web at Catemaco. The abundance and biomass of plankton ciliates are high at the study site compared with that of other shallow freshwater ecosystems, and they are likely the main picoplankton grazers at Catemaco because phagotrophic nanoflagellates are not abundant. This condition appears to be the result of large cladocera exclusion, either by selective fish predation or decreased filtering efficiency because of high filamentous cyanobacteria densities. The size class composition of these ciliates also suggests that they are the most probable prey for the first-feeding fish larvae of the species that sustain the local fisheries; thus, plankton ciliates may be a critical factor for appropriate recruitment.

\section{ACKNOWLEDGMENTS}

Program ECOS-NORD France-Mexique ECOS No. MIOA01 funded a short stay by the first author at Marseille, France, through the research project "Impact of anthropic perturbations on the microbial communities of a tropical shallow ecosystem: Laguna de Sontecomapan, state of Veracruz." Dr. Marc Pagano of the Luminy Oceanological Center at Marseille made all of the necessary arrangements for a successful stay. The contributions of three anonymous referees, which improved the original manuscript, are also acknowledged.

\section{REFERENCES}

Agasild H, Zingel P, Karus K, Kangro K, Salujõe J, Nõges T, 2013. Does metazooplankton regulate the ciliate community in a shallow eutrophic lake? Freshwater Biol. 58:183-191.

APHA, 1992. Standard methods for the examination of water and wastewater, $18^{\text {th }}$ ed. American Public Health Association.

Auer B, Elzer U, Arndt H, 2004. Comparison of pelagic food webs in lakes along a trophic gradient and with seasonal aspects: influence of resource and predation. J. Plankton Res. 26:697-709.

Bagatini IL, Spínola ALG, Peres BM, Mansano AS, Rodrigues MaA, Batalha MA, Lucca JV, Gondinho MJL, Tundisi TM, Seleghim MHR, 2013. Protozooplankton and its relationship with environmental conditions in 13 water bodies of the Mogi-Guaçu basin - SP, Brazil. Biota Neotrop. 13:152-163.

Beaver JR, Crisman TL, 1982. The trophic response of ciliated protozoans in freshwater lakes. Limnol. Oceanogr. 27: 246-253. 
Beaver JR, Crisman TL, 1989. Analysis of the community structure of planktonic ciliated protozoa relative to trophic state in Florida lakes. Hydrobiologia 174:177-184.

Beaver R, Crisman T, 1990. Seasonality of planktonic ciliated protozoa in 20 subtropical Florida lakes of varying trophic state. Hydrobiologia 190:127-135.

Berry JP, Lind O, 2010. First evidence of "paralytic shellfish toxins" and cylindrospermopsin in a Mexican freshwater system, Lago Catemaco, and apparent bioaccumulation of the toxins in "tegogolo" snails (Pomacea patula catemacensis). Toxicon 55:930-938.

Burian A, Schagerl M, Yasindi A, 2013. Microzooplankton feeding behaviour: grazing on the microbial and the classical food web of African soda lakes. Hydrobiologia 710:61-72.

Callieri C, Stockner JG, 2002. Freshwater autotrophic picoplankton: a review. J. Limnol. 6:1-14.

Combes A, Dellinger M, Cadel-Six S, Amand S, Comte K, 2013. Ciliate Nassula sp. grazing on a microcystin-producing cyanobacterium (Planktothrix agardhii): impact on cell growth and in the microcystin fractions. Aquat. Toxicol. 126:435- 441.

Chróst RJ, Tomasz A, Kalinowska K, Skowronska A, 2009. Abundance and structure of microbial loop components (Bacteria and Protists) in lakes of different trophic status. J. Microbiol. Biotechnol. 19:858-868.

Davis TW, Koch F, Marcoval MA, Wilhelmb SW, Gobler CJ, 2012. Mesozooplankton and microzooplankton grazing during cyanobacterial blooms in the western basin of Lake Erie. Harmful Algae 15:26-35.

Dragesco J, Dragesco-Kernéis A, Fryd-Versavel G, 1986. [Ciliés libres de l'Afrique intertropicale. Introduction à la connaissance et à l'étude des Ciliés].[Book in French]. ORSTOM, Paris: 562 pp.

Engström-Öst J, Autio R, Setälä O, Sopanen S, Suikkanen S, 2013. Plankton community dynamics during decay of a cyanobacteria bloom: a mesocosm experiment. Hydrobiologia 701:25-35.

Esquivel A, Soto-Castor R, Figueroa-Torres G, Moreno-Ruiz JL, Torres-Orozco BRE, 2009. [Diagnóstico del estado trófico y de la calidad bacteriológica del agua, sedimento y caracol ( $P o$ macea patula catemacensis) del lago de Catemaco], p. 71-83. In: L. Ayala-Pérez, R. Gío-Argáez and N. Trigo-Boix (eds.), [Contribuciones Metodológicas al Conocimiento de los Recursos Naturales].[Book in Spanish]. Universidad Autónoma Metropolitana Xochimilco, Instituto de Ciencias del Mar y Limnología UNAM, Sociedad Mexicana de Historia Natural.

Fabbro L, Baker M, Duivenvoorden L, Pegg G, Shiel R, 2001. The effects of the ciliate Paramecium cf. caudatum Ehrenberg on toxin producing Cylindrospermopsis isolated from the Fitzroy River, Australia. Environ. Toxicol. 16:489-497.

Foissner W, Berger H, 1996. A user-friendly guide to the ciliates (Protozoa, Ciliophora) commonly used by hydrobiologists as bioindicators in rivers, lakes, and waste waters, with notes on their ecology. Freshwater Biol. 35:375-482.

Foissner W, Berger H, Schaumburg J, 1999. Identification and ecology of limnetic plankton ciliates. Bavarian State Office for Water Management.

Gifford DJ, Caron DA, 2000. Sampling, preservation, enumeration and biomass of marine protozooplankton, p. 193-221. In: R. Harris, P. Wiebe, J. Lenz, H.R. Skjoldal and M. Huntley (eds.), ICES Zooplankton methodology manual. Elsevier.
Gomes EAT, Godinho MJL, 2003. Structure of the protozooplankton community in a tropical shallow and eutrophic lake in Brazil. Acta Oecol. 24:S153-S161.

Hasle GR, 1978. The inverted-microscope method, p. 88-96. In: A. Sournia (ed.), Phytoplankton Manual. Monographs on oceanographic methodology 6. UNESCO.

Havens KE, James RT, East TL, Smith VH, 2003. N:P ratios, light limitation, and cyanobacterial dominance in a subtropical lake impacted by non-point source nutrient pollution. Environ. Pollut. 122:379-390.

Havens KE, Beaver JR, East TL, 2007. Plankton biomass partitioning in a eutrophic subtropical lake: comparison with results from temperate lake ecosystems. J. Plankton Res. 29: 1087-1097.

Hillebrand H, Dürselen C-D, Kirschtel D, Pollingher U, Zohary T, 1999. Biovolume calculation for pelagic and benthic microalgae. J. Phycol. 35:403-424.

Hisatugo KF, Mansano AS, Seleghim MHR, 2014. Protozoans bacterivory in a subtropical environment during a dry/cold and a rainy/warm season. Braz. J. Microbiol. 45:143-151.

Hunter JR, 1981. Feeding ecology and predation of marine fish larvae, p. 34-77. In: R. Lasker (ed.), Marine fish larvae. Morphology, ecology and relation to fisheries. Washington Sea Grant Program. University of Wahington Press.

Idso SB, Gilbert RG, 1974. On the universality of the Poole and Atkins Secchi disk-light extinction equation. J. Appl. Ecol. 11:399-401.

Jeffrey W, Humphrey F, 1975. New spectrophotometric equations for determining chlorophylls a, b, c1 and c2 in higher plants, algae and natural phytoplankton. Biochem. Physiol. Pflanz 167:191-194.

Jürgens K, Arndt H, Zimmermann H, 1997. Impact of metazoan and protozoan grazers on bacterial biomass distribution in microcosm experiments. Aquat. Microb. Ecol. 12:131-138.

Jürgens K, Pernthaler J, Schalla S, Amann R, 1999a. Morphological and compositional changes in a planktonic bacterial community in response to enhanced protozoan grazing. Appl. Environ. Microbiol. 65:1241-1250.

Jürgens K, Skibbe O, Jeppesen E, 1999b. Impact of metazooplankton on the composition and population dynamics of planktonic ciliates in a shallow, hypertrophic lake. Aquat. Microb. Ecol. 17:61-75.

Jürgens K, Jeppesen E, 2000. The impact of metazooplankton on the structure of the microbial food web in a shallow hypertrophic lake. J. Plankton Res. 22: 1047-1070.

Kepner RL, Pratt JR, 1993. Effects of sediments on estimates of bacterial density. Trans. Am. Microsc. Soc. 112:316-330.

Komárková J, Tavera R, 1996. Cyanoprokaryota (Cyanobacteria) in the phytoplankton of Lake Catemaco (Veracruz, Mexico). Algol. Stud. 83:403-422.

Komárková J, Tavera R, 2003. Steady state of phytoplankton assemblage in the tropical Lake Catemaco (Mexico). Hydrobiologia 502:187-196.

Kosten S, Huszar VLM, Becares E, Costa LS, Van Donk E, Hansson LA, Jeppesenk E, Kruk C, Lacerot G, Mazzeo N, De Meester L, Moss B, Lurling M, Noges T, Romo S, Scheffer M, 2012. Warmer climates boost cyanobacterial dominance in shallow lakes. Global Change Biol. 18:118-126.

Lasker R, 1981. The role of a stable ocean in larval fish survival and subsequent recruitment, p. 80-87. In: R Lasker (ed.), Ma- 
rine fish larvae. Morphology, ecology and relation to fisheries. Washington Sea Grant Program. University of Wahington Press.

Lewis MJ, 1985. Protozoan abundance in the plankton of two tropical lakes. Arch. Hydrobiol. 104:337-343.

Lynn DH, 2008. The Ciliated Protozoa. Characterization, Classification, and Guide to the Literature, 3rd ed. Springer Science.

Macek M, Peštová D, Martínez-Pérez ME, 2008. Seasonal and spatial dynamics of a ciliate assemblage in a warm-monomictic Lake Alchichica (Puebla, Mexico). Hidrobiológica 18:25-35.

Machado-Velho LF, Lansac-Toha FM, Bressan-Buosi PR, De Meira BR, Cabral AF, Lansac-Toha FA, 2013. Structure of planktonic ciliates community (Protist, Ciliophora) from an urban lake of southern Brazil. Acta Sci. Biol. Sci. 35:531-539.

Machado-Velho LF, Pereira DG, Pagioro TA, Santos VD, Perenha MCZ, Lansac-Töha FA, 2005. Abundance, biomass and size structure of planktonic ciliates in reservoirs with distinct trophic states. Acta Limnol. Bras. 17:361-371.

Maluf-Barbieri S, Godinho-Orlandi MJL, 1989. Ecological studies on the planktonic protozo of a eutrophic reservoir (Rio Grande Reservoir - Brazil). Hydrobiologia 183:1-10.

Miller RR, Van Conner J, 1997. [Peces de Catemaco], p. 451456. In: E. González-Soriano, R. Dirzo and R.C. Vogt (eds.), [Historia Natural de Los Tuxtlas].[Book in Spanish]. Universidad Nacional Autónoma de México.

Mills MM, Moore CM, Langlois R, Milne A, Achterberg E, Nachtigall K, Lochte K, Geider RJ, La Roche J, 2008. Nitrogen and phosphorus co-limitation of bacterial productivity and growth in the oligotrophic subtropical North Atlantic. Limnol. Oceanogr. 53:824-834.

Mischler JA, Taylor PG, Townsend AR, 2014. Nitrogen limitation of pond ecosystems on the plains of Eastern Colorado. PLoS ONE 9:e95757.

Montagnes DJS, Lynn DH, 1987. A quantitative protargol stain (QPS) for ciliates: method description and test of its quantitative nature. Mar. Microb. Food Webs 2:83-93.

Montagnes DJS, Lynn DH, 1993. A quantitative protargol stain (QPS) for ciliates and other protists, p. 229-240. In: P.F. Kemp, B.F. Sherr, E.B. Sherr, J.J. Cole (eds.), Handbook of methods in aquatic microbial ecology. Lewis Publishers.

Moustaka-Gouni M, Vardaka E, Michaloudi E, Kormas KA, Tryfon E, Mihalatou H, Gkelis S, Lanaras T, 2006. Plankton food web structure in a eutrophic polymictic lake with a history in toxic cyanobacterial blooms. Limnol. Oceanogr. 51:715-727.

Ozen A, Bucak T, Tavsanoglu UN, Cakiroglu AI, Levi EE, Coppens J, Jeppesen E, Beklioglu M, 2014. Water level and fishmediated cascading effects on the microbial community in eutrophic warm shallow lakes: a mesocosm experiment. Hydrobiologia 740:25-35.

Pace L, Orcutt D, 1981. The relative importance of protozoans, rotifers and crustaceans in a freshwater zooplankton community. Limnol. Oceanogr. 26:822-830.

Pérez-Rojas A, Torres-Orozco BRE, 1992. Geomorfología y batimetría del lago de Catemaco, Veracruz, México. An. Inst. Cienc. Mar Limnol. Univ. Nac. Auton. Mex. 19:19-24.

Pernthaler J, 2005. Predation on prokaryotes in the water column and its ecological implications. Nat. Rev. Microbiol. 3:537-546.

Peštová D, Macek M, Martínez-Pérez ME, 2008. Ciliates and their picophytoplankton-feeding activity in a high-altitude warm-monomictic saline lake. Eur. J. Protistol. 44:13-25.

Pfister G, Auer B, Arndt H, 2002. Pelagic ciliates (Protozoa, Ciliophora) of different brackish and freshwater lakes- a community analysis at the species level. Limnologica 32:147-168.

Porter KG, Feig YS, 1980. The use of DAPI for identifying and counting aquatic microflora. Limnol. Oeanogr. 25:943-948.

Putt M, Stoecker DK, 1989. An experimentally determined carbon: volume ratio for marine "oligotrichous" ciliates from estuarine and coastal waters. Limnol. Oceanogr. 34:1097-1103.

Reynolds CS, Huszar V, Kruk C, Naselli-Flores L, Melo S, 2002. Towards a functional classification of the freshwater phytoplankton. J. Plankton Res. 24:417-428.

Salcher MM, 2014. Same same but different: ecological niche partitioning of planktonic freshwater prokaryotes. J. Limnol.73:74-87.

Sanders RW, Leeper DA, King CH, Porter KG, 1994. Grazing by rotifers and crustacean zooplankton on nanoplanktonic protists. Hydrobiologia 288:167-181.

Sarmento H, Unrein F, Isumbisho M, Stenuite S, Gasol JM, Descy J-P, 2008. Abundance and distribution of picoplankton in tropical, oligotrophic Lake Kivu, eastern Africa. Freshwater Biol. 53:756-771.

Sarmento H, 2012. New paradigms in tropical limnology: the importance of the microbial food web. Hydrobiologia 686:1-14.

Scura ED, Jerde CW, 1977. Various species of phytoplankton as food for larval northern anchovy Engraulis mordax, and relative nutriotional value of the dinoflagellates Gymnodinium splendens and Gonyaulax polyedra. U.S. Fish. Bull. 75:577-583.

Sherr EB, Sherr BF, 2002. Significance of predation by protists in aquatic microbial food webs. Antonie van Leeuwenhoek 81:293-308.

Shukla U, Gupta K, 2001. Assemblage of ciliated protozoan community in a polluted and non-polluted environment in a tropical lake of central Himalaya: Lake Naini Tal, India. J. Plankton Res. 23:571-584.

Šimek K, Bobková J, Macek M, Nedoma J, Psenner R, 1995. Ciliate grazing on picoplankton in a eutrophic reservoir during the summer phytoplankton maximum: A study at the species and community level. Limnol. Oceanogr. 40:1077-1090.

Skibbe O, 1994. An improved quantitative protargol stain for ciliates and other planktonic protists. Arch. Hydrobiol. 130:339-347.

Sokal RR, Rohlf FJ, 2012. Biometry: the principles and practice of statistics in biological research, $4^{\text {th }}$ ed. W. H. Freeman and Co.

Sommer U, Sommer F, Santer B, Zöllner E, Jürgens K, Jamieson C, Boersma M, Gocke K, 2003. Daphnia versus copepod impact on summer phytoplankton: functional compensation at both trophic levels. Oecologia 135:639-647.

Song B, 2000. A comparative study on planktonic ciliates in two shallow mesotrophic lakes (China): species composition, distribution and quantitative importance. Hydrobiologia 427: 143-153.

Straškrabová V, Callieri C, Carrillo P, Cruz-Pizarro L, Fott J, Hartman P, Macek M, Medina-Sánchez JM, Nedoma J, Šimek K, 1999. Investigations on pelagic food webs in mountain lakes - aims and methods, p. 77-87. In: V. Straškrabová, C. Callieri 
and J. Fott (eds.), Pelagic food web in mountain lakes. MOuntain LAkes Research Program. J. Limnol.

Tavera R. 1996. Phytoplankton of the tropical lake Catemaco. University of South Bohemia.

Torres-Orozco BRE, Jiménez-Sierra C, Pérez-Rojas A, 1996. Some limnological features of three lakes from Mexican neotropics. Hydrobiologia 341:91-99.

Torres-Orozco BRE, Pérez-Rojas A, 1995. [El lago de Catemaco], p. 155-175. In: G. de la Lanza and J.L. GarcíaCalderón (eds.), [Lagos y Presas de México].[Book in Spaniish]. Centro de Ecología y Desarrollo.

Torres-Orozco BRE, Zanatta SA, 1998. Species composition, abundance and distribution of zooplankton in a tropical eutrophic lake: Lake Catemaco, Mexico. Rev. Biol. Trop. 46: 285-296.

Van Wichelen J, Johansson LS, Vanormelingen P, Declerck SaJ, Lauridsen TL, De Meester L, Jeppesen E, Vyverman W, 2013. Planktonic ciliate community structure in shallow lakes of lowland Western Europe. Eur. J. Protistol. 49:538-551.

Ventela A-M, Wiackowski K, Moilanen M, Saarikari V, Vuorio K, Sarvala J, 2002. The effect of small zooplankton on the microbial loop and edible algae during a cyanobacterial bloom. Feshwater Biol. 47:1807-1819.

Weisse T, Frahm A, 2002. Direct and indirect impact of two common rotifer species (Keratella spp.) on two abundant ciliate species (Urotricha furcata, Balanion planctonicum). Feshwater Biol. 47:53-64.

Wetzel RG, 2001. Limnology. Lake and river ecosystems, 3rd ed. Academic Press: 1006 pp.

Yasindi AW, Taylor WD, 2003. Abundance, biomass and estimated production of planktonic ciliates in Lakes Victoria and Malawi. Aquat. Ecosys. Health 6:289-297.

Zingel P, Agasild H, Tiina N, Kisand V, 2007. Ciliates are the dominant grazers on pico- and nanoplankton in a shallow, naturally highly eutrophic lake. Microb. Ecol. 53:134-142.

Zingel P, Nõges T, 2010. Seasonal and annual population dynamics of ciliates in a shallow eutrophic lake. Fundam. Appl. Limnol. Arch. Hydrobiol. 176:133-143.

Zingel P, Paaver T, Karus K, Agasild H, Nõges T, 2012. Ciliates as the crucial food source of larval fish in a shallow eutrophic lake. Limnol. Oceanogr. 57:1049-1056. 